\title{
ANALISIS KEMAMPUAN PENALARAN MATEMATIS MAHASISWA PADA MATA KULIAH STRUKTUR ALJABAR II (TEORI GELANGGANG)
}

\author{
Guntur Maulana Muhammad \\ Universitas Suryakancana \\ guntur@unsur.ac.id
}

\begin{abstract}
ABSTRAK
Penelitian ini bertujuan untuk mengetahui sejauh mana kemampuan penalaran matematis mahasiswa dalam mata kuliah Struktur Aljabar II. Hasil dari penelitian ini menjadi dasar untuk perbaikan pembelajaran mata kuliah Struktur Aljabar II kedepan. Metode penelitian yang digunakan adalah metode deskriptif kuantitatif dengan subjek penelitian mahasiswa tingkat III TA 2016/2017 yang mengambil mata kuliah Struktur Aljabar II pada program studi pendidikan matematika, Universitas Suryakancana. Kesimpulan dari penelitian ini adalah kemampuan penalaran matematis yang dimiliki mahasiswa tingkat III yang diukur pada proses evaluasi setelah pembelajaran mata kuliah Struktur Aljabar II masih kurang meskipun tidak pada tahapan rendah terbukti pencapaian rata-ratanya hanya $48.23 \%$, sebagian besar mahasiswa masih mengalami kesulitan dalam menjawab soal pembuktian atau belum terampil dalam membuktikan suatu teorema/proposisi, serta kesalahan yang sering terjadi adalah dalam pengaplikasian konsep/teorema/pengetahuan sebelumnya untuk menunjukkan suatu hal yang belum terbukti kebenarannya.
\end{abstract}

Kata kunci : Kemampuan Penalaran Matematis, Struktur Aljabar II.

\section{PENDAHULUAN}

Dalam Pedoman Mata Pelajaran Matematika, Peraturan Menteri Pendidikan dan Kebudayaan Republik Indonesia No.59 tahun 2014 dinyatakan bahwa tujuan mata pelajaran matematika adalah agar peserta didik dapat: memahami konsep matematika; menggunakan pola sebagai dugaan dalam pemecahan masalah; menggunakan penalaran dalam rangka memecahkan masalah rutin maupun tidak rutin; mengomunikasikan gagasan, penalaran serta mampu menyusun bukti; memiliki sikap menghargai kegunaan matematika dalam kehidupan; memiliki sikap yang sesuai dengan nilai-nilai dalam matematika dan pembelajarannya; menggunakan kegiatan-kegiatan motorik yang menggunakan pengetahuan matematika; serta menggunakan alat peraga sederhana maupun hasil teknologi untuk melakukan kegiatankegiatan matematika. 
Jurnal PRISMA Universitas Suryakancana

Proses pencapaian tujuan tersebut tidaklah mudah, banyak faktor yang terkait dengan proses pembelajaran matematika. Motivasi, kemampuan dasar peserta didik, kondisi lingkungan, metode pembelajaran, sarana dan prasaran serta faktor lainnya yang walaupun kecil tetapi memiliki andil dalam pencapaian tujuan pembelajaran matematika. Hal ini tidak hanya terjadi pada peserta didik di tingkat sekolah menengah tetapi juga terjadi pada mahasiswa di pendidikan tinggi. Dalam proses belajarnya, mahasiswa lebih diberikan kebebasan dalam mencari informasi terkait materi mata kuliah yang diambilnya karena sebagian besar dosen menerapkan pembelajaran yang berpusat pada mahasiswa (student center), atau setidaknya sebagian-sebagian (50\% mahasiswa, 50\% dosen).

Pembelajaran matematika di perguruan tinggi tidak sama dengan pembelajaran matematika di sekolah menengah. Di perguruan tinggi, khususnya program studi pendidikan matematika, yang sebagian besar mata kuliahnya terkait teori dasar matematika, pembelajaran matematika lebih dasar dan spesifik. Matematika yang diajarkan di sekolah menengah adalah implementasi teori-teori atau hukum-hukum matematika yang diajarkan di perguruan tinggi, sehingga dalam proses belajarnya mahasiswa harus lebih jeli dalam mempelajari materi pada setiap mata kuliah.

Salah satu mata kuliah yang diajarkan di perguruan tinggi pada program studi pendidikan matematika adalah Struktur Aljabar II (Teori Gelanggang). Struktur Aljabar II merupakan mata kuliah lanjutan dari Struktur Aljabar I. Secara keseluruhan kedua mata kuliah ini tergabung dalam Aljabar Abstrak (Struktur Aljabar I dan II). Tujuan dari mempelajari Aljabar Abstrak ini adalah agar mahasiswa mampu melakukan proses abstraksi dan generalisasi dalam matematika melalui objek-objek aljabar yang abstrak.

Dalam Aljabar Abstrak dipelajari hukum dasar dari semua operasi yang diajarkan di sekolah menengah. Berawal dari himpunan dan definisi-definisi yang ada dan melalui proses induktif dan deduktif, maka berkembanglah struktur tersebut sampai dengan Gelanggang dengan teorema-teorema yang masih dapat diperluas. Oleh sebab itu, dengan kegiatan induktif dan deduktif mahasiswa dituntut menguasai kemampuan penalaran matematis.

Shadiq (2014 : 25) menyatakan bahwa penalaran merupakan kegiatan, proses, atau aktivitas berpikir untuk menarik suatu kesimpulan atau membuat suatu pernyataan baru 
berdasar pada beberapa pernyataan yang diketahui benar maupun yang dianggap benar. Menurut Copi (Shadiq, 2014:25), "Reasoning is a special kind of thinking in which inference takes place, in which conclusions are drawn from premises". Penalaran matematika merupakan kebiasaan pikiran dan harus dikembangkan secara konsisten dalam berbagai konteks (NCTM, 2000; Kaur dan Lam, 2012). Kemampuan penalaran bergantung pada pengetahuan awal seseorang. Berdasarkan pengetahuan awal, seseorang membuat kesimpulan sehingga terjadi hubungan sebab-akibat. Daya nalar lah yang bisa membuat seseorang membuktikan suatu hukum dalam matematika bernilai benar atau salah berdasarkan faktafakta yang ada. Dalam tingkatan sekolah menengah, Kurikulum 2013 yang tertuang dalam Permen No.59 tahun 2014 mencantumkan kemampuan menggunakan penalaran menjadi salah satu tujuan pembelajaran matematika.

Dalam tingkatan perguruan tinggi tujuan pembelajaran bergantung pada mata kuliah. Untuk mata kuliah Struktur Aljabar II, tujuannya agar mahasiswa mampu melakukan proses abstraksi dan generalisasi dalam matematika melalui objek-objek aljabar abstrak. Artinya, diperlukan kemampuan penalaran matematis dalam pembelajaran mata kuliah Struktur Aljabar II. Dengan tujuan mata kuliah Struktur Aljabar II yang menekankan pada kemampuan penalaran, mahasiswa dituntut untuk belajar lebih keras.

Universitas Suryakancana merupakan perguruan tinggi swasta di Cianjur. Sebagai perguruan tinggi yang sedang berkembang, tidak dipungkiri bahwa sumber daya yang masuk tidak seperti sumber daya yang ada di perguruan tinggi negeri. Kondisi inilah yang membuat dosen-dosen di Universitas Suryakancana, khususnya prodi. Pendidikan Matematika, bekerja keras untuk memahamkan materi mata kuliah pada mahasiswa. Oleh karena itu, diperlukan data sebagai pertimbangan dalam pengembangan pembelajaran terutama pada pembelajaran mata kuliah Struktur Aljabar II. Data inilah yang memberikan deskripsi sejauh mana kemampuan penalaran mahasiswa setelah pembelajaran. Untuk itulah dilakukan penelitian ini.

\section{METODE PENELITIAN}

Penelitian ini merupakan penelitian kualitatif dengan pendekatan deskriptif. Peneliti terjun langsung ke lapangan untuk mengukur kemampuan penalaran matematis mahasiswa pada mata kuliah Struktur Aljabar II. Dilihat dari subjek penelitian, populasinya semua 
mahasiswa tingkat III TA. 2016-2017 Universitas Suryakancana yang mengambil mata kuliah Struktur Aljabar II (Teori Gelanggang), dengan kata lain mahasiswa tingkat III TA. 2016-2017 menjadi populasi dari penelitian ini. Oleh karena itu, sampel dari penelitian ini adalah populasinya atau dalam istilah lain penelitian ini merupakan Penelitian Populasi. Jumlah mahasiswa tingkat III TA. 2016-2017 yang menjadi sampel adalah sebanyak 66 orang.

Tabel 1. Distribusi Soal terhadap Indikator Penalaran

\begin{tabular}{clc}
\hline No. & \multicolumn{1}{c}{ Indikator Penalaran Matematis } & No Soal \\
\hline 1. & $\begin{array}{l}\text { Menyajikan pernyataan matematika secara lisan, } \\
\text { tertulis, gambar, dan diagram }\end{array}$ & 1 dan 3 \\
\hline 2. & $\begin{array}{l}\text { Melakukan manipulasi matematika } \\
\text { 3. }\end{array}$ & $\begin{array}{l}\text { Menarik kesimpulan, menyusun bukti, } \\
\text { memberikan alasan atau bukti terhadap beberapa } \\
\text { solusi }\end{array}$ \\
\hline 4. & Memeriksa kesahihan suatu argumen & 2 dan 4 \\
\hline
\end{tabular}

Adapun jumlah soal yang disusun untuk Ujian Tengah Semester mata kuliah Struktur Aljabar II sebanyak 5 soal, semua soal terdistribusi pada indikator pengukur kemampuan penalaran matematis (Tabel 1.) yang diadopsi Peraturan Dirjen Dikdasmen No. 506/C/PP/2004 (Shadiq, 2014:51).

1. Menyajikan pernyataan matematika secara lisan, tertulis, gambar, dan diagram,

2. Mengajukan dugaan (conjecture),

3. Melakukan manipulasi matematika,

4. Menarik kesimpulan, menyusun bukti, memberikan alasan, atau bukti terhadap beberapa solusi,

5. Menarik kesimpulan dari pernyataan,

6. Memeriksa kesahihan suatu argumen,

7. Menemukan pola atau sifat dari gejala matematis untuk membuat generalisasi.

Dalam hal ini peneliti mengambil empat dari tujuh indikator di atas. 
Jurnal PRISMA Universitas Suryakancana

HASIL DAN PEMBAHASAN

Hasil Penelitian (Kemampuan Penalaran Matematis)

Tabel 2. Statistik Deskriptif Skor Kemampuan Penalaran Mahasiswa

\begin{tabular}{cccccc}
\hline & N & Min & Maks & Rerata & SD \\
\hline Skor & 66 & 1 & 21 & 11.58 & 5.63 \\
\hline
\end{tabular}

Tabel 2. menunjukkan bahwa dari 66 orang mahasiswa terdapat mahasiswa yang mendapatkan skor terendah 1 dan skor tertinggi 21 dari skor ideal 24. Rata-rata skor secara keseluruhannya adalah 11.58 dengan standar deviasi 5.63 .

Tabel 3. Distribusi Skor terhadap Banyaknya Mahasiswa

\begin{tabular}{|c|c|c|c|c|c|c|c|c|c|}
\hline & \multicolumn{5}{|c|}{$\begin{array}{l}\text { Banyaknya yang } \\
\text { memperoleh skor- }\end{array}$} & \multirow[t]{2}{*}{ Jumlah } & \multirow[t]{2}{*}{ Terbanyak } & \multicolumn{2}{|c|}{$\begin{array}{c}\text { Persentase } \\
(\%)\end{array}$} \\
\hline & 4 & 3 & 2 & 1 & $\mathbf{0}$ & & & & \\
\hline $\begin{array}{c}\text { Soal no.1 } \\
\text { indikator } 1\end{array}$ & 11 & 26 & 1 & 6 & 22 & 66 & 3 & 39.39 & 56.06 \\
\hline $\begin{array}{c}\text { Soal no.3 } \\
\text { indikator } 1\end{array}$ & 13 & 48 & 0 & 0 & 5 & 66 & 3 & 72.73 & \\
\hline $\begin{array}{c}\text { Soal no.2 } \\
\text { indikator } 2\end{array}$ & 19 & 21 & 0 & 6 & 20 & 66 & 3 & 31.82 & 31.82 \\
\hline $\begin{array}{c}\text { Soal no.2 } \\
\text { indikator } 3\end{array}$ & 8 & 12 & 14 & 12 & 20 & 66 & 0 & 30.30 & 43.94 \\
\hline $\begin{array}{c}\text { Soal no.4 } \\
\text { indikator } 3\end{array}$ & 7 & 5 & 1 & 15 & 38 & 66 & 0 & 57.58 & \\
\hline $\begin{array}{c}\text { Soal no.5 } \\
\text { indikator } 4\end{array}$ & 4 & 30 & 0 & 19 & 13 & 66 & 3 & 45.45 & 45.45 \\
\hline
\end{tabular}

Data pada tabel 3. yang diolah dengan Microsoft Excel 2007 menunjukkan bahwa jawaban mahasiswa pada soal nomor 1 dengan indikator ke-1 lebih banyak yang mendapatkan skor 3 yaitu sebanyak 26 orang. Akan tetapi mahasiswa lainnya mendapatkan skor 0 dengan jumlah yang tidak jauh dari yang mendapatkan skor 3, yaitu sebanyak 22 orang. Artinya masih banyak mahasiswa (33.33\%) yang memang tidak dapat memberikan jawaban atau tidak berusaha untuk menjawab. Soal nomor 1 merupakan soal yang menuntut pemahaman konsep, sehingga dengan memahami konsep mahasiswa diharapkan dapat menggunakan daya nalarnya untuk menentukan sebuah contoh atau mengintegrasikan konsep terhadap suatu hal yang bersifat induktif. 


\section{Soal no.1 indikator 1}

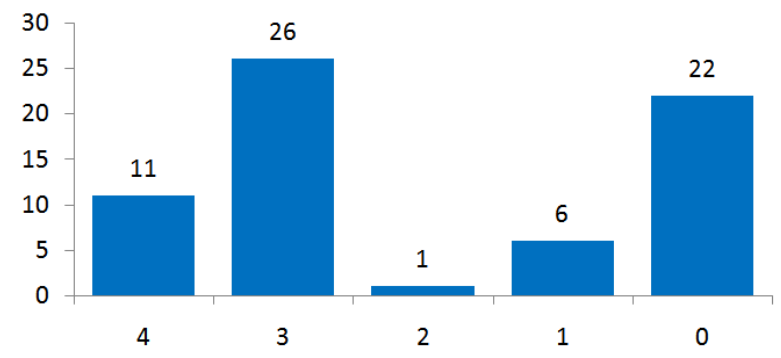

\section{Gambar 1. Sebaran skor mahasiswa terhadap soal no.1 indikator 1}

Untuk soal nomor 3 dengan indikator ke-1 yang ditunjukkan oleh tabel 2, terlihat bahwa mayoritas mahasiswa mencoba memberikan jawaban. Hanya 5 orang $(7.58 \%)$ yang tidak memberikan jawaban sama sekali. Soal nomor 3 merupakan soal yang prosedural. Soal yang dapat dijawab hanya dengan menerapkan suatu algoritma. Tipe soal seperti ini dapat dijawab walaupun hanya dengan menghafal tanpa perlu memahami.

\section{Soal no.3 indikator 1}

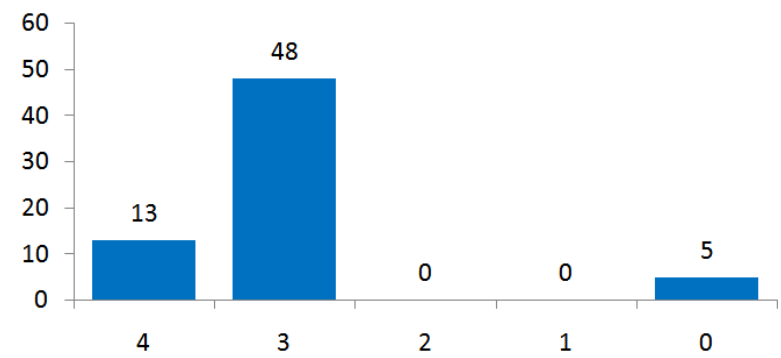

\section{Gambar 2. Sebaran skor mahasiswa terhadap soal no.3 indikator 1}

Untuk soal nomor 2 dengan indikator ke-2 yang ditunjukkan oleh tabel 2, terlihat bahwa 21 orang mahasiswa (31.82\%) mampu menjawab soal dengan melakukan manipulasi matematika walaupun jawabannya salah. Sedangkan 19 orang (28.79\%) mampu melakukan manipulasi matematika dan menjawab dengan benar. Artinya lebih dari 50\% mahasiswa dapat melakukan manipulasi matematika. Tipe soal nomor 2 merupakan soal yang menuntut kemampuan penalaran deduktif. Mahasiswa harus memahami soal dan mengetahui teorema- 
teorema yang bisa digunakan untuk memperkuat argumennya sehingga terbukti kebenaran dari suatu pernyataan tersebut. Pada soal ini sebanyak 20 orang (30.30\%) tidak memberikan jawaban, yang mengindikasikan mahasiswa tersebut tidak memahami soal atau tidak memahami konsep yang harus diterapkan pada soal tersebut atau bahkan tidak mengetahui bagaimana cara menjawab soal seperti soal nomor 2 .

\section{Soal no. 2 indikator 2}

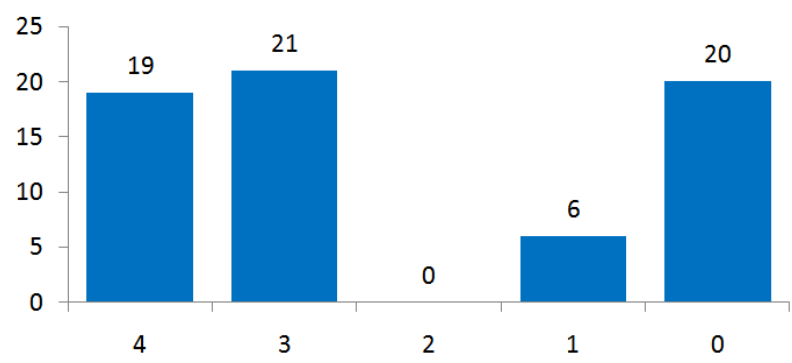

\section{Gambar 3. Sebaran skor mahasiswa terhadap soal no.2 indikator 2}

Jika sebelumnya jawaban soal nomor 2 dilihat dari indikator ke-2, sekarang jawaban soal nomor 2 akan dilihat dari indikator nomor 3. Pada sudut pandang ini yang dilihat adalah kemampuan mahasiswa dalam menentukan kesimpulan. Tidak sedikit mahasiswa yang mampu melakukan manipulasi tapi tidak dapat menyimpulkan hasil dari manipulasi yang dilakukannya. Terbukti pada soal nomor 2 sebanyak 20 orang mahasiswa $(30.30 \%)$ tidak mampu menyusun bukti dan tidak dapat membuat kesimpulan meskipun kesimpulan yang salah. Hal ini mengindikasikan bahwa mahasiswa tidak memahami soal sehingga tidak memahami cara menjawab soal tersebut. Kemungkinan lain mahasiswa memahami soal tetapi tidak memahami konsep sehingga tidak dapat menggunakan daya nalarnya untuk menjawab soal tersebut. 


\section{Soal no. 2 indikator 3}

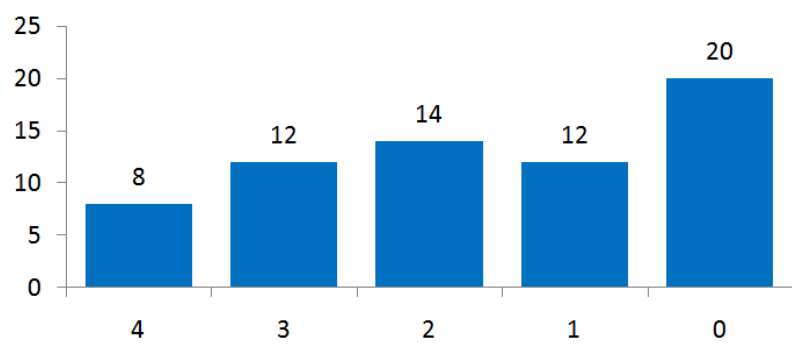

\section{Gambar 4. Sebaran skor mahasiswa terhadap soal no.2 indikator 3}

Soal nomor 4 dengan indikator ke-3 mempunyai karakteristik yang sama dengan soal nomor 2. Keduanya merupakan soal pembuktian, menuntut kemampuan penalaran deduktif mahasiswa. Pada soal nomor 4 ini dengan indikator ke-3, mayoritas mahasiswa (38 orang dari total 66 orang atau 57.58\%) tidak memberikan jawaban terhadap soal tersebut. Hal ini mengindikasikan bahwa mahasiswa tidak memahami soal sehingga tidak memahami cara menjawab soal tersebut. Kemungkinan lain mahasiswa memahami soal tetapi tidak memahami konsep sehingga tidak dapat menggunakan daya nalarnya untuk menjawab soal tersebut.

\section{Soal no.4 indikator 3}

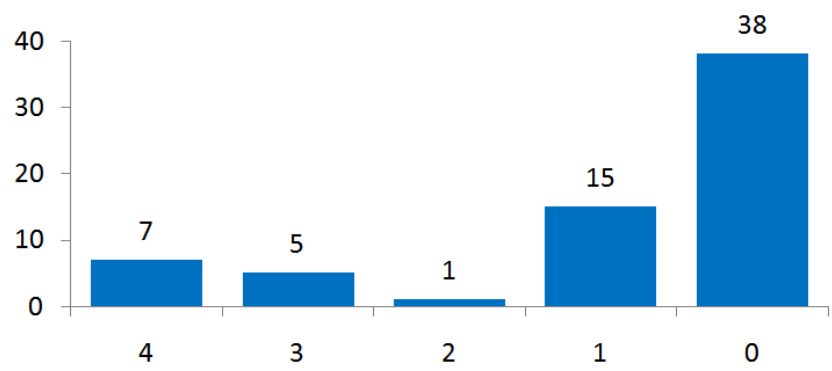

\section{Gambar 5. Sebaran skor mahasiswa terhadap soal no.4 indikator 3}

Pada soal nomor 5 dengan indikator ke-4 terlihat bahwa 30 orang mahasiswa dari 66 orang $(45.45 \%)$ dapat memeriksa kesahihan suatu argumen dan memberikan jawaban tetapi salah. Peneliti mengkategorikan soal nomor 5 ini ke dalam soal yang mudah, akan tetapi yang mendapatkan skor 4 dari 66 orang mahasiswa hanya 4 orang. Kemungkinan mahasiswa tidak memahami maksud dari soal atau maksud peneliti terhadap jawaban yang dimaksud. 


\section{Soal no.5 indikator 4}

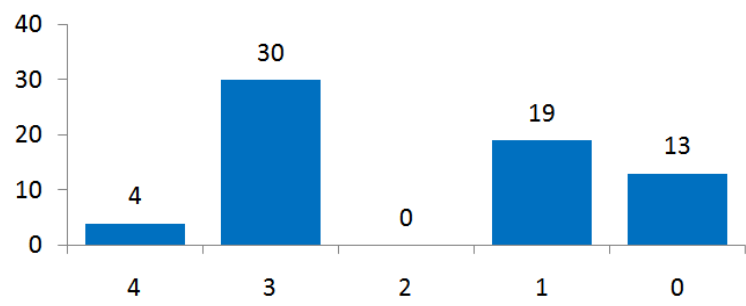

Gambar 6. Sebaran skor mahasiswa terhadap soal no.5 indikator 4

Secara umum persentase kemampuan penalaran mahasiswa pada proses evaluasi ini mencapai 48.23\% (lihat Tabel 4). Sehingga dapat disimpulkan bahwa secara umum mahasiswa tidak dapat menggunakan daya nalarnya secara maksimal dalam menjawab soalsoal yang disediakan dalam proses evaluasi. Tentu akan banyak kemungkinan yang menyebabkan hal tersebut, diantaranya mahasiswa tidak memahami konsep yang disampaikan dalam pembelajaran Struktur Aljabar II, kurangnya kemampuan mahasiswa dalam menggunakan pengetahuan yang ada, dan kurangnya kemampuan mahasiswa dalam menghubungkan konsep-konsep yang telah dipelajari.

Tabel 4. Persentase Kemampuan Penalaran Matematis Mahasiswa

\begin{tabular}{lccccccc}
\hline Indikator & & $\mathbf{1}$ & $\mathbf{2}$ & & $\mathbf{3}$ & $\mathbf{4}$ & $\begin{array}{c}\text { Pencapaian } \\
\text { rata-rata }\end{array}$ \\
\hline Soal nomor & $\mathbf{1}$ & $\mathbf{3}$ & $\mathbf{2}$ & $\mathbf{2}$ & $\mathbf{4}$ & $\mathbf{5}$ & 1.93 \\
\hline Rata-rata & 1.97 & 2.97 & 2.20 & 1.64 & 0.91 & 1.89 & $48.23 \%$
\end{tabular}

\section{Pembahasan Kesulitan dan Kesalahan Jawaban Mahasiswa}

Berdasarkan tingkat kesulitan soal tidak semua mahasiswa dapat menyelesaikan soal yang bersifat mudah, dan sebaliknya terdapat beberapa mahasiswa yang mampu menyelesaikan soal yang bersifat sulit. Semua tergantung pada kemampuan penalaran matematis mahasiswa. Misalnya pada soal nomor 1, dengan tipe soal sedang ada beberapa mahasiswa yang dapat menyelesaikan dan ada pula yang tidak. Soal nomor 1 menuntut mahasiswa berpikir induktif. Menggunakan pemahamannya terhadap konsep gelanggang untuk menentukan contoh konkrit gelanggang. Memahami contoh gelanggang kemudian menerapkan konsep gelanggang pada contoh lainnya. Kebanyakan mahasiswa tidak 
mengetahui cara membuktikan bahwa suatu himpunan termasuk gelanggang atau bukan meskipun sebenarnya mereka mengetahui syarat-syarat yang menjadikan suatu himpunan merupakan gelanggang. Selain itu banyak juga mahasiswa yang memaksakan sifat suatu gelanggang pada himpunan yang tersedia di soal. Akan tetapi di sisi lain kebanyakan mahasiswa berusaha menjawab soal nomor 1 walaupun jawaban mereka salah.

Pada dasarnya untuk menunjukkan bahwa suatu himpunan dengan dua operasi merupakan gelanggang atau bukan adalah dengan menduga terlebih dahulu. Jika dugaannya himpunan tersebut merupakan gelanggang, maka harus ditunjukkan bahwa himpunan tersebut memenuhi semua persyaratan gelanggang. Tetapi jika dugaannya himpunan tersebut bukan gelanggang, maka cukup ditunjukkan contoh/salah satu syarat gelanggang yang tidak terpenuhi oleh himpunan tersebut. Kesalahan yang mahasiswa lakukan kebanyakan memaksakan semua syarat gelanggang terpenuhi oleh $\mathbb{Z}-\{5\}$, walaupun sebenarnya tidak.

Pada soal nomor 2, 30.30\% mahasiswa tidak menjawab sama sekali. Soal ini merupakan soal pembuktian sebuah teorema. Kesulitan pada soal pembuktian kebanyakan mahasiswa tidak mengetahui langkah awal yang harus dilakukan. Mereka tidak bisa mengambil informasi awal dari teorema yang harus dibuktikan. Pada soal tertulis "jika $R$ suatu lapangan", dari situ sebenarnya banyak informasi yang bisa digali. Kesulitan mahasiswa adalah mereka tidak mengetahui akibat/konsekuensi dari suatu himpunan yang merupakan lapangan. Sebagai contoh, konsekuensi dari $R$ suatu lapangan adalah $R$ juga suatu gelanggang dengan setiap unsurnya mempunyai invers.

Selain kesulitan dalam membuktikan teorema, mahasiswa juga seringkali lupa dalam menyimpulkan. Sebanyak 46 orang mahasiswa dari 66 orang (69.70\%) tidak menarik kesimpulan dari pembuktian soal nomor 2. Hal ini bisa terjadi karena lupa atau mungkin mereka tidak memahami apa yang mereka tulis sehingga tidak dapat menyimpulkan. Untuk kesalahan yang sering dilakukan mahasiswa, mereka seringkali menggunakan teorema yang akan dibuktikan untuk menunjukkan kebenaran teorema tersebut. Hal tersebut salah, karena tidak mungkin kita menggunakan suatu hal yang belum jelas kebenarannya untuk menunjukkan kebenaran hal tersebut. 
Jurnal PRISMA Universitas Suryakancana

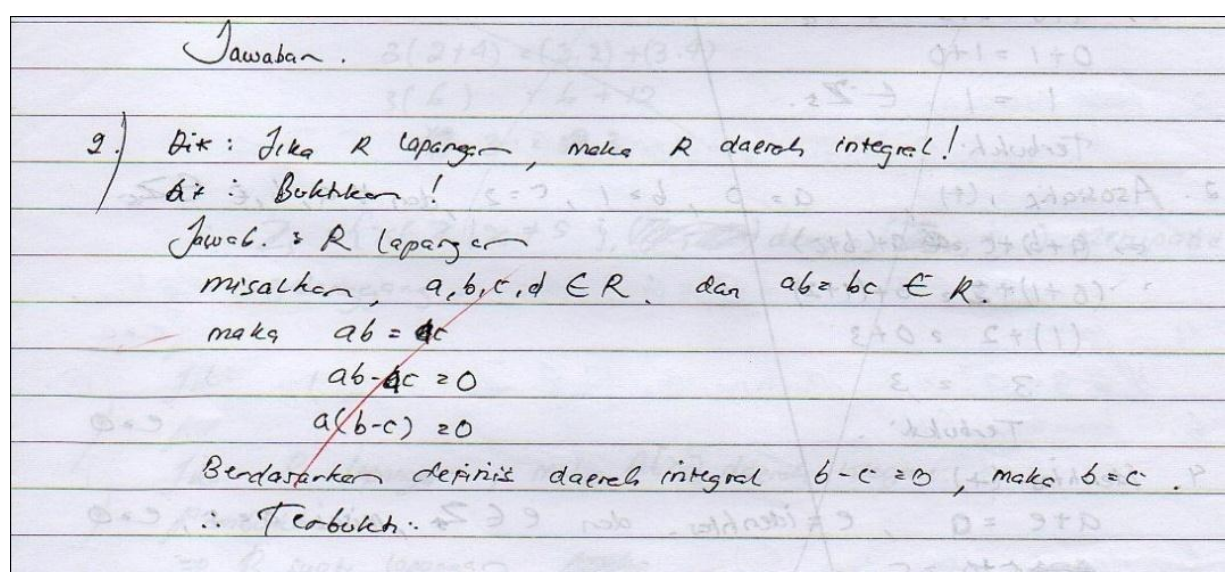

Gambar 7. Contoh Jawaban Salah Mahasiswa Untuk Soal Nomor 2.

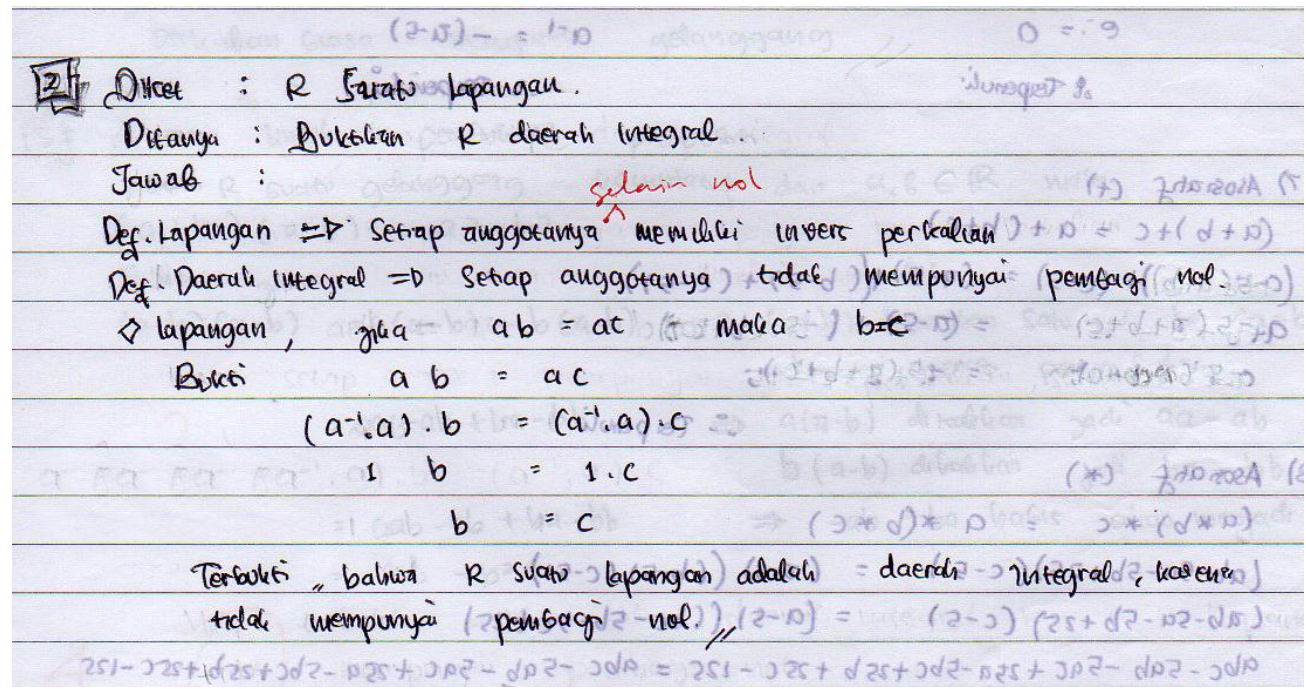

Gambar 8. Contoh Jawaban Benar Mahasiswa Untuk Soal Nomor 2.

Soal nomor 3 termasuk soal dengan kategori mudah, buktinya 13 orang mahasiswa (19.70\%) menjawab dengan benar dan 48 orang mahasiswa (72.73\%) menjawab dengan menggunakan algoritma yang benar walaupun jawaban di akhirnya masih salah. Kesulitan yang terjadi dalam menjawab soal ini adalah ketika mahasiswa tidak mengingat dengan baik algoritma yang harus digunakan. Algoritma yang digunakan dalam menjawab soal ini cukup dengan algoritma Euclid yang dikombinasi dengan pembagian terhadap suku banyak. Sama halnya seperti dalam menentukan gcd untuk dua bilangan bulat. Algoritma Euclid tersebut sebenarnya sudah diajarkan pada mata kuliah Teori Bilangan pada tingkat I. Pada soal nomor 
5 ini hanya lima orang mahasiswa saja yang tidak memberikan jawaban sama sekali dengan asumsi peneliti bahwa mereka lupa atau kurangnya motivasi belajar, karena sejatinya soal ini mudah untuk dikerjakan. Untuk kesalahan yang sering dilakukan mahasiswa, mereka seringkali salah menentukan posisi gcd pada hasil akhir pengerjaan dengan menggunakan algoritma Euclid. Selain itu banyak juga yang ceroboh dalam melakukan pembagian suku banyak.

Dari lima soal evaluasi terdapat dua soal dengan tipe yang sama, yaitu soal nomor 2 dan nomor 4. Keduanya merupakan soal pembuktian yang menuntut kemampuan penalaran deduktif mahasiswa. Pada dasarnya kesulitan pada soal nomor 4 ini sama dengan soal nonor 2 , yaitu mahasiswa tidak mengetahui langkah awal yang harus dilakukan. Mereka tidak bisa mengambil informasi awal dari teorema yang harus dibuktikan. Selain itu, mereka tidak mengetahui akibat/konsekuensi dari suatu himpunan yang merupakan lapangan. Untuk membuktikan teorema pada soal nomor 4 ini mahasiswa juga harus mengetahui beberapa teorema yang berlaku pada gelanggang suku banyak, terutama yang berkaitan dengan derajat suku banyak. Untuk kesalahan yang sering dilakukan mahasiswa, terkadang mereka menggunakan teorema sendiri. Misalnya $\operatorname{der}(1)=\sim$ atau $\operatorname{der}(0)=0$. Selain itu mahasiswa juga terkadang salah dalam menggunakan teorema.

Pada soal nomor 5, sebenarnya peneliti berharap mahasiswa mudah dalam menyelesaikannya. Akan tetapi hasilnya hanya 4 orang mahasiswa dari 66 orang yang menjawab dengan benar, dan 13 orang mahasiswa tidak memberikan jawaban. Dalam menyelesaikan soal nomor 5 ini hanya menuntut hafalan mahasiswa terhadap sifat-sifat dasar operasi seperti asosiatif, distributif, dan yang lainnya. Dengan melihat pekerjaan mahasiswa, kesulitan yang dialami adalah mahasiswa tidak ingat dengan sifat-sifat dasar operasi. Selain itu mereka seperti tidak mengetahui bagaimana cara menjawab soal nomor 5 atau tidak mengetahui jawaban yang diinginkan dari pembuat soal.

\section{KESIMPULAN}

Kemampuan Penalaran Matematis yang dimiliki mahasiswa tingkat III yang diukur pada proses evaluasi setelah pembelajaran mata kuliah Struktur Aljabar II masih kurang meskipun tidak pada tahapan rendah. Terbukti pencapaian rata-ratanya hanya $48.23 \%$. 
Jurnal PRISMA Universitas Suryakancana

Sebagian besar mahasiswa masih mengalami kesulitan dalam menjawab soal pembuktian atau belum terampil dalam membuktikan suatu teorema/proposisi. Kesalahan yang sering terjadi adalah dalam pengaplikasian konsep/teorema/pengetahuan sebelumnya untuk menunjukkan suatu hal yang belum terbukti kebenarannya.

\section{REKOMENDASI}

Dalam hal ini peneliti merasa perlu dalam memberikan saran sesuai dengan hasil dan pembahasan penelitian.

1. Pengetahuan prasyarat yang diberikan terkait dengan mata Kuliah Struktur Aljabar II harus dikuasai betul oleh mahasiswa.

2. Pemberian latihan soal yang berulang dapat membiasakan mahasiswa dalam mengatasi kesulitan serta masalah yang tak rutin.

3. Penyediaan bahan ajar yang mudah didapatkan dan mudah dipahami serta dapat dipelajari sendiri oleh mahasiswa, seperti modul yang disesuaikan dengan karakter mahasiswa Universitas Suryakancana.

4. Dosen harus mencoba alternatif metode pembelajaran lain yang disesuaikan dengan karakteristik mahasiswa agar mahasiswa dapat lebih memahami materi Struktur Aljabar II.

\section{REFERENSI}

Kaur, B., \& Lam, T.T. (2012). Reasoning, Communication, and Connections in Mathematics. Singapore: Worlds Scientific.

NCTM. (2000). Principles and Standards for School Mathematics. USA: The National Council of Theachers of Mathematics,Inc.

Shadiq, Fadjar. (2014). Pembelajaran Matematika: Cara Meningkatkan Kemampuan Berpikir Siswa. Yogyakarta: Graha Ilmu. 